\title{
The story of a knowledge-based and learning organization
}

\author{
Jan Hjelte \\ Umeå socialtjänsten (Umeå Social Services) \\ Email: jan.hjelte@umea.se
}

\section{Kristina Westerberg}

Department of Psychology

Umeå University

Email: kristina.westerberg@psy.umu.se

\begin{abstract}
Knowledge is generally viewed as one of the most important organizational resources, and this view is also held in relation to municipal elderly-care organizations. However, the concept of a knowledge-based organization has seldom been addressed in elderly-care research. The aim of the present study was to analyse how political and professional groups involved in elderly care conceive of the idea of a knowledge-based organization, and how these conceptions relate to their expectations in relation to the future of elderly care. This issue is important because these conceptions are intertwined with actions conducted by organizational members. Participants were selected for the study on the basis of organizational level and engagement in the development of different kinds of care in an elderly-care organization in a large municipality. A narrative approach was used for data analysis. The study indicates that the interpretations of a knowledge-based organization bring stability and meaning to participants by linking elderly care, as it is in the present, to an image of its future. Furthermore, the narratives are adjusted depending on what kind of problems that organization is expected to solve. However, the participants do not view the economic resources of the organization as something they can
\end{abstract}


influence and develop, in either the present or the future. The study also shows that there are multiple perspectives in regard to the meaning of a knowledge-based organization and, accordingly, multiple perspectives on what will need to be done in the future. This is a potential problem for elderly care because it can hinder the coordination of organizational activities and the ability to handle the challenges of the future. Therefore the results point to the importance of creating within the organization a shared meaning of its main problems, and to the contribution a knowledge-based organization can make in solving these problems.

Keywords: Knowledge-based organization, elderly care, narrative analysis, multiple perspectives

\section{Introduction}

Knowledge is generally viewed as one of the most important organizational resources in regard to performance (Ma \& Yu, 2010; Wang \& Noe, 2010). One example is social services, where it has been argued that it is important that the entire organization, including staff and management, base their decisions on scientific knowledge (Denvall, 2008) while also systematically valuing the knowledge of users and practitioners (Nixon \& Murr, 2006). In Sweden, the political governing boards of municipalities are responsible for social-welfare services. Elderly care is an important part of social-welfare services, and has struggled for many years owing to a lack of trained staff. Also, the location of elderly care has shifted from hospitals to community-based facilities and private homes (Arnetz \& Hasson, 2007; Boström et al., 2007). In addition, municipal elderly-care services face the challenge of managing the growing number of elderly people in need of assistance, and, in turn, the expected increasing need to recruit new employees (SALAR, 2006). The current state and future challenges have been addressed in general, but the extent to which professionals working in the field perceive elderly care as a knowledge-based organization has received only limited attention. However, it has been shown that there are different views on, and understandings of, the concept of knowledge-based elderly care on different organizational and political levels (Westerberg et al., 2011), and that politicians and managers in elderly-care services do not always share an understanding of those services and how they should be delivered and developed (Henriksen \& Rosenqvist, 2003). 
Given the challenges faced by elderly-care services, the divergent conceptions of knowledge and how to develop the organization are of concern. In order to develop a knowledge-based organization, it is important to develop the ability to transfer knowledge and a shared meaning of knowledge within the organization (Wang \& Noe, 2010). Problems could arise if staff, management, and politicians differ significantly in their understanding of what constitutes a knowledge-based organization (Westerberg et al., 2011). The perceptions and conceptions of the current situation are therefore important when planning for the future organizational structure (Henriksen \& Rosenqvist, 2003). Furthermore, the actions taken to develop a knowledge-based organization are intertwined with the idea of such an organization (Boreham \& Morgan, 2004; Nixon \& Murr, 2006).

The aim of the present study was to analyse how political and professional groups conceive of the concept of a knowledge-based organization in the elderly-care services and how these conceptions shape their expectations of the future of those services.

\section{A narrative approach}

In order to capture the perceptions and conceptions of a knowledge-based organization, a narrative approach was used. Such an approach involves the analysis of stories through which individuals recount events, actions, and objects in their lives (Pentland, 1999; Sias et al., 2004). People also use narratives to express emotions and beliefs about how things should be (Fraser, 2004) and to clarify the legitimacy of different actions (Czarniawska, 1997).

The literature contains a variety of definitions of narrative. In general, these definitions converge on the notion that narratives elaborate a sequence of events that are linked to a subject (theme) or time. Alternatively, they depict a temporal transition from one state to another (Chreim, 2007). We used a thematic perspective on narratives, which means that we analysed the use of a label or its synonyms (Chreim, 2005). Analysing the use of labels is useful in organizational studies because it can create an understanding of the central characteristics and general direction of the organization (Chreim, 2005).

We chose to use a narrative approach because the real, everyday operation of most organizations is based on narratives in which important experiences are often used as rules of thumb (Weick, 1995). Hence, a narrative approach allows an understanding of interpretation and sense-making in organizations (Chreim, 2007). The narrative approach is especially useful in research on activities where people work together on a social level - which is the case in 
elderly care - because mutual understanding is a central part of the end result (Blom \& Nygren, 2010; Salander, 2002).

Because narratives can be used to create rules of thumb, they also have a constitutive function through which stories contribute not only to the preservation of, but also to the changes within organizations. In regard to such changes, narratives about what is possible or what other organizations have accomplished provide useful models for what needs to be done (Pentland, 1999). When changes arise, it may be necessary to find options for the reinterpretation of an organization's assignments, and also to link these changes to key symbols from the past (Chreim, 2005). Therefore narratives are temporal because they can be modified, nuanced, and adjusted to the needs of changes that occur (De Fina \& Georgakopoulou, 2008).

The narrative approach is one method used to analyse the structure of both written and verbal communication. Traditionally, narratives have been seen as a technique for recounting past experience. As a consequence, narratives about ongoing, future or hypothetical events have been neglected (De Fina \& Georgakopoulou, 2008). To clarify the dual role of the narrative in creating both continuity and change, it is relevant to focus on narratives about both the current course of events and the (organizational) future. As Weick (1995) points out, it is necessary to look to the future as well as the past in order to construct an understanding of events. Accordingly, the narratives that the analysis in this study focuses on include not only those about events that have already taken place, but also those about actors' anticipations of the future of elderly care.

\section{The interview study}

This study was conducted within a municipal social-services organization of approximately 2800 employees in a fairly large municipality in Sweden. The organization provides family and child services, as well as care for elderly and disabled persons. About 1800 employees work directly in or have supportive functions in elderly care. Elderly care is thus the largest department within the social-services organization. Elderly care had, for a number of years, been handled specifically with the aim of developing a knowledge-based organization and had received governmental funds to achieve this. These funds were initiated by the Swedish government, and municipal elderly-care authorities could apply in order to support activities, such as courses and workplace improvements, for long-term development of quality and skills in that field. The elderly-care organization in the present study participated with the aim of building new infrastructures for learning and improving the quality of care, and stressed the use of evidenced-based practice and knowledge 
transfer within the organization (Svanström, 2008). In addition, in the local operational plan for 2009, the Board for Social Welfare and the social administration stated that during the period 2009-2011 the social services would 'develop and enter deeply into the knowledge-based organization' (VP, 2009).

\section{Participants}

An organization is characterized by the many voices that contribute to different and sometimes highly divergent versions of that organization (Chreim, 2005). Therefore, the selection of participants for the interview study was made on the basis of organizational level and engagement in the development of different kinds of elderly care. Two of the initially selected managers declined to participate, and consequently two other managers were chosen.

Twelve individual and four group interviews were conducted. The participants in individual interviews were two local politicians who were members of the local Board for Social Welfare, three senior managers in the organization, four persons belonging to the management staff, two project managers, and one assistant nurse who worked part-time as a pedagogical supervisor. The four groups that participated were: a) the process group (a team of assistant nurses, an occupational therapist, and unit managers who were working together part-time on a project concerning workplace change processes); b) the elderly-care team (a team of specialized nurses, occupational therapists, physiotherapists, and a dietician, working primarily in staff education and supervision, and with the elderly with specific needs); and c) seven assistant nurses from two work groups operating in elderly individuals' homes. ${ }^{1}$

The process team, the elderly-care team, the pedagogical supervisor and the project managers may be referred to as 'change agents' within the organization, that is, practitioners assigned to a specific responsibility of organizational development (Chase, 1997). They worked horizontally across the traditional vertical organizational structure (the line organization) and their work was temporary in the sense that their functions were introduced within a project context with the support of external funds.

\footnotetext{
${ }^{1}$ In Sweden, the elderly typically live in their own homes and have access to home-help services.
} 


\section{Procedure}

Prior to the interview, selected participants were sent a letter with information about the purpose of the study and the selection process. The letter also indicated the anticipated length of the interview, that recording equipment would be used during the interview, and that participation was voluntary. Additionally, participants were informed that only the team of researchers would have access to the recorded material. At the time of interview the participants were again provided with this information. They were also told that their statements would be presented at a group level, for instance, as politicians or managers.

The individual interviews had a duration of approximately 45 minutes, the group interviews with the change agents lasted about two hours, and the group interviews with the work groups were about one hour long. The interviews were conducted at the participants' workplace or, for the change agents' groups, in their meeting room. There were four different interviewers (including the authors). For each individual interview there was one interviewer and for each group interview there were two.

An interview manual was used for the interviews. This manual included questions about knowledge and knowledge transfer, as well as questions about resources, shared visions, and communication. The theoretical point of departure was from a socio-cultural perspective (Engeström, 2001; Boreham \& Morgan, 2004), but the questions were open-ended and descriptive. The following are examples of questions included in the manual: 'When I say knowledge-based elderly care - what comes to mind?' 'What sources of knowledge should the knowledge base of elderly care be built on?' 'What kinds of resources are required to achieve knowledge-based elderly care?' One question focused on the future of elderly care and was formulated as follows: 'Is there a shared vision of future knowledge-based elderly care in this organization?'

\section{Analysis}

Narrative material can be analysed in several dimensions, for example, content, structure or style of speech. As mentioned above, we used a thematic perspective to the narrative analysis, interpreting the content of themes in the context of the whole text (cf. Lieblich et al., 1998). The analysis was carried out in four phases.

Phase 1. Coding of individual interviews - content and temporal codings. Qualitative methods generally involve some type of coding with the purpose of analysing how respondents impose order on their experiences to make sense 
of events and actions in their lives (Chreim, 2007). In this study we conducted two sorts of coding, content and temporal orientation. The coding of content was initially made with descriptive codes that were relatively close to the empirical material. Thereafter the content was coded on a more abstract level where the codes were more inferential (Miles \& Huberman, 1994). The coding of temporal orientation was twofold: the present and the future. The present consisted of themes that described the respondent's view of the organization at the time of the study, and included past experiences that were related to the formation of their present perceptions. The future related to themes that described the respondent's view of the organization in the future. In the same way that experiences from the past contributed to the formation of perceptions of the present, experiences in the present were related to ideas about the future. Taken together, the content- and temporal-orientation codings yielded a coherent narrative for each respondent.

Phase 2. Aggregation of dominant themes for different professional groups. In this phase, the themes that were dominant for each of the professional groups were analysed (cf. Fraser, 2004).

Phase 3. Comparison of dominant themes between professional groups. Next, commonalities and differences between the professional groups' dominant themes were analysed. Researchers have recognized that the listing of the material and the naming of the themes make such commonalities and differences visible (cf. Fraser, 2004). The themes were classified into three major areas: the problem, the prerequisites, and the communicational processes.

Phase 4. Theoretical interpretation. Finally, the material was analysed in relation to theory and previous research.

\section{Results}

In the analysis the themes were classified into three overarching areas based on content: a) the problems, b) the prerequisites, and c) the communicational processes. In the following sections the themes are presented by area. The perceptions of functional categories (politicians, managers, administrative staff, change agents, and assistant nurses) are presented separately when there are differences between them.

\section{A. The problems}

This area includes two themes, one that expresses the present problems and another that describes the anticipated problems related to developing a knowledge-based organization (Table 1). 
Table1. Themes related to the problem areas

\begin{tabular}{lll} 
Category & The present problem & The future problem \\
\hline All categories & $\begin{array}{l}\text { Imbalance in the } \\
\text { knowledge base of elderly } \\
\text { care }\end{array}$ & $\begin{array}{l}\text { Increasing demands on } \\
\text { and expectations of elderly } \\
\text { care }\end{array}$
\end{tabular}

\section{The present problem}

Imbalance in the knowledge base of elderly care:_Respondents across all the categories shared the opinion that the basic problem impeding the development of a knowledge-based organization in elderly care was the emphasis on experience-based knowledge. Furthermore, there was a sentiment that the organization needs to draw on varied sources of knowledge in order to provide the highest level of care to the elderly. The problem was not the use of experience-based knowledge per se, but the lack of balance between the different sources of knowledge, especially scientific and experience-based knowledge. The imbalance was described as something that exists within the entire organization, from the care workers to the housing planners. One example of these sentiments is the following (translated) statement made by one of the managers:

We have a problem in elderly care because we often base our actions on feelings only. This is very easy in a relation-oriented work. We need to rely on science and what is really tested to a larger extent. (Manager 3)

Even though all categories agreed that the basic problem was imbalance, they had different opinions on the reason for the imbalance. According to the politicians the reason was a lack of available scientific knowledge in many areas. The managers, the staff and change agents described other reasons for the imbalance. One prevalent opinion was that elderly care has a history of not valuing theoretical and scientific knowledge, which implies that there is a degree of resistance to scientific knowledge.

\section{The future problem}

Increasing demands and expectations: All the categories acknowledged that, in the future, elderly care would face increasing demands and expectations. The staff and the change agents were of the opinion that the increasing number of elderly people was one of the causes. Politicians, change agents, 
and assistant nurses also opined that the imminent entrance of the large generation born in the 1940s into the sphere of elderly care would increase demands for service and, further, that present conditions in elderly care would fail to meet these individuals' expectations.

\section{Key points of present and future problems}

All categories agreed on the primary problems facing both the present and future of elderly care. However, a variety of problems were mentioned, which implies that a knowledge-based organization is expected to be able to deal with many types of dilemmas, both now and in the future. In the present, the main problem is imbalance in the knowledge base of elderly care. Earlier studies have formulated the experience of caring work as a rationality of caring that could not be improved by formal education and scientific knowledge (Waerness, 1996). Later research has indicated that occupational learning in elderly care is largely based on experience in everyday work (Törnquist, 2004; Ellström and Ekholm, 2001). However, the need for scientific knowledge has been supported by Swedish authorities as a means for updated and informed professionalism in elderly care (SOU 2007:88), and large competence and education programmes have been launched (Ministry of Health and Social Affairs, 2007). Furthermore, all of the categories in the present study anticipate that there will be increased demands on and expectations of elderly care. This anticipation has been described in research as well as by authorities (SALAR, 2006), and is generally considered a challenge.

\section{B. The prerequisites}

There were three themes that emerged related to prerequisites in the organization: limited economic resources, leadership and governance, and learning structures. The themes are presented in Table 2, classified within the functional categories.

\section{The present prerequisites}

Limited economic resources: All the categories, with the exception of managers, mentioned the financial situation and its impact on the development of a knowledge-based organization. They all referred to the cutbacks that have been made in elderly care over recent years and how these had affected the options for pursuing developmental work within the organization:

... sometimes the discussion on economic issues takes over totally and then the developmental perspective disappears until the economic issues have calmed down again. (Staff 3) 
Table 2. Themes related to prerequisites

\begin{tabular}{|c|c|c|}
\hline Category & Present prerequisites & Future prerequisites \\
\hline Politicians & $\begin{array}{l}\text { Limited economic resources } \\
\text { Deficiencies in leadership and } \\
\text { governance } \\
\text { Deficiencies in learning } \\
\text { structures }\end{array}$ & $\begin{array}{l}\text { Limited economic resources } \\
\text { Explicit leadership and } \\
\text { governance } \\
\text { New learning structures }\end{array}$ \\
\hline Managers & $\begin{array}{l}\text { Deficiencies in leadership and } \\
\text { governance } \\
\text { Deficiencies in learning } \\
\text { structures }\end{array}$ & $\begin{array}{l}\text { Explicit leadership and } \\
\text { governance } \\
\text { New learning structures }\end{array}$ \\
\hline Staff & $\begin{array}{l}\text { Limited economic resources } \\
\text { Deficiencies in leadership and } \\
\text { governance } \\
\text { Deficiencies in learning } \\
\text { structures }\end{array}$ & $\begin{array}{l}\text { Limited economic resources } \\
\text { Explicit leadership and } \\
\text { governance } \\
\text { New learning structures }\end{array}$ \\
\hline Change agents & $\begin{array}{l}\text { Limited economic resources } \\
\text { Deficiencies in leadership and } \\
\text { governance } \\
\text { Deficiencies in learning } \\
\text { structures }\end{array}$ & $\begin{array}{l}\text { Limited economic resources } \\
\text { Explicit leadership and } \\
\text { governance } \\
\text { New learning structures }\end{array}$ \\
\hline $\begin{array}{l}\text { Assistant } \\
\text { nurses }\end{array}$ & $\begin{array}{l}\text { Limited economical resources } \\
\text { Deficiencies in learning } \\
\text { structures }\end{array}$ & New learning structures \\
\hline
\end{tabular}

Deficiencies in leadership and governance: All categories, with the exception of assistant nurses, stressed leadership and governance as factors that send signals about what is important to the organization. All categories that mentioned leadership and governance implied that there were shortcomings in these areas within the organization. One example is the comment below.

One starts to wonder when it [decisions aren't implemented] goes on year after year whether there is a leader somewhere that can give the direction. (Politician 2) 
Deficiencies in learning structures: All categories indicated that in order to achieve balanced, knowledge-based elderly care, there must be wellfunctioning structures for learning. Time and space to reflect on one's work together with colleagues was considered an important part of such structures. According to staff, this was missing in the present organization. Another aspect of learning structures that was mentioned was access to change agents. Managers, staff, and assistant nurses described change agents as distributors of knowledge and partners for reflection on care work. However, perceptions varied in regard to what extent change agents were available to participate in developmental work in practice. The staff and assistant nurses thought there was a shortage of change agents, while the managers thought there were sufficient numbers available.

\section{The future prerequisites}

Limited economic resources: As mentioned earlier, the large, soon-to-beelderly generation born in the 1940s is expected to be more demanding than previous generations, and this implies a future greater need for both focus on the users and quality of care. Limited economic resources were expected to be the primary obstacle to such improvements. According to politicians, staff and change agents there will be an imbalance between demand for services and financial resources and, because of that imbalance, the gap between users' expectations and organizational resources will widen. The anticipated increased number of elderly in need of assistance is expected to further strain limited financial resources. Owing to the changing conditions, politicians, managers, staff, and change agents thought that the organization needed to become more effective and that this could be managed by increased knowledge.

Explicit leadership and governance: In order to become more effective it was thought necessary, according to all categories apart from assistant nurses, to develop a more explicit leadership and governance within the organization. This was considered essential in the transition from words to actions. The managers claimed, for instance, that there must be clear guidelines regarding what is expected of employees in elderly care. In addition, according to managers, staff, and change agents, such guidelines should exist for all employees, and not only the care staff. The politicians also talked about guidelines, but in the context of how feedback to the political board should be developed. One politician described the need for guidelines in the following comment:

I have struggled with this since I became a member of the board ... that the politicians set the agenda for how things should be executed and then others can do it. The board is responsible for all. You have to have 
control instruments that enable one to govern and these can give you a reasonable feedback to the board. (Politician 2)

New learning structures: All categories mentioned that it was essential to create new learning structures in the future. The politicians referred to a more overreaching plan to change the structures, but the staff stressed the time and space necessary for reflection. Managers, change agents, and assistant nurses pointed out that there was a need to adapt the forms of workplace learning to the context of practice. This was expressed by one of the managers in the following example:

We have, like all in elderly care, worked on the collective solution, in groups as large as was possible and with as many persons as was possible. We have to rethink. To think more on an individual level also when it comes to enhancing staff competence. Smaller groups, fewer persons. How else could you learn something new in home care service where you work alone in the users' homes? (Manager 3)

\section{Key points of present and future prerequisites}

To a large extent, the prerequisites that were described as problems in the present recurred in relation to the future, as developmental needs. The exception was economic resources, which were portrayed as a restriction in both the present and the future. There were differences between categories with regard to opinions about the prerequisites, and even when they all emphasized the same prerequisite, differences of opinion remained. For example, all categories mentioned the importance of learning structures, but there were differences in their emphases and also in their perceptions of how well such structures functioned. In an extensive study of elderly care in Sweden, Gustafsson and Szebehely (2005) found differences between organizational levels in the perception of working conditions and steering. The perception of the work environment as strained increased with position in the organizational hierarchy. Nursing assistants reported having the heaviest workload, the least influence, and the greatest lack of resources. The politicians' influence over the economy was perceived as high by other categories but not by the politicians themselves. The authors discuss whether this reflects the restrictions outside the control of municipal politicians, and how these restrictions are partly related to the practices of New Public Management (Gustafsson and Szebehely, 2005). 
Table 3. Themes related to the communicational processes

\begin{tabular}{|c|c|c|}
\hline Category & $\begin{array}{l}\text { Present communicational } \\
\text { processes }\end{array}$ & $\begin{array}{l}\text { Future communicational } \\
\text { processes }\end{array}$ \\
\hline Politicians & - & - \\
\hline Managers & $\begin{array}{l}\text { Deficiencies in knowledge } \\
\text { transfer } \\
\text { Well-functioning workplace } \\
\text { learning }\end{array}$ & $\begin{array}{l}\text { New methods of knowledge } \\
\text { transfer }\end{array}$ \\
\hline Staff & $\begin{array}{l}\text { Deficiencies in knowledge } \\
\text { transfer } \\
\text { Deficiencies in workplace } \\
\text { learning }\end{array}$ & $\begin{array}{l}\text { Development of workplace } \\
\text { learning }\end{array}$ \\
\hline Change agents & $\begin{array}{l}\text { Deficiencies in knowledge } \\
\text { transfer } \\
\text { Deficiencies in workplace } \\
\text { learning }\end{array}$ & $\begin{array}{l}\text { New methods of knowledge } \\
\text { transfer } \\
\text { Development of workplace } \\
\text { learning }\end{array}$ \\
\hline Assistant nurses & $\begin{array}{l}\text { Deficiencies in workplace } \\
\text { learning }\end{array}$ & - \\
\hline
\end{tabular}

\section{The communicational processes}

The themes related to the communicational processes concerned different qualities in regard to two major topics: knowledge transfer and workplace learning (Table 3).

\section{The present communicational processes}

Deficiencies in knowledge transfer: In order to achieve a knowledge-based organization with a balance between different sources of knowledge, it seemed important systematically to transfer externally sourced knowledge and to make it available to all workers. However, managers, staff, and change agents indicated that there were deficiencies in the organization that made this transfer problematic. One manager mentioned, as an example, that the organization was stuck in a routine of offering theoretical courses, and there 
was a need to investigate how the system could be expanded in order for employees to gain access to research-based knowledge.

Workplace learning: Another important aspect of communication was, according to managers, staff, change agents, and assistant nurses, that workplace learning was expected to be realized in developmental work and supported by change agents. However, opinions varied on the success of workplace learning. Managers expressed the opinion that there were many opportunities for workplace learning with the help of change agents, but the staff, change agents, and assistant nurses did not agree. The latter categories expressed the view that learning was basically an activity within the limits of a work unit. The change agents thought it was hard to create learning opportunities in home-care services, while the assistant nurses described workplace learning as the oral transfer of experience-based knowledge in specific situations when a problem had occurred and the work group learned from each other and exchanged experiences.

\section{The future communicational processes}

New methods of knowledge transfer: To be able to meet the anticipated demands and expectations it was, according to managers and change agents, necessary to find new ways of improving knowledge transfer. One change agent stated that research and scientific knowledge must become closely grounded and integrated in the work activity. This knowledge would promote independence in acting and thinking, in contrast to reliance on manuals and guidelines.

Development of workplace learning: In accordance with the statements about the present, staff and change agents also talked about the need to develop workplace learning in the future. One reason given for the importance of future workplace learning development was that it would enable a greater amount of critical reflection among workers, and consequently reduce the amount of wasteful activity based only on routines and guidelines.

\section{Key points of present and future communicational processes}

As was the case with the prerequisites, deficiencies in the communicational processes of the present reappear in the future as developmental needs. Also, in relation to the communicational processes, there are differences between the functional categories. For example, the change agents saw the future developmental needs of both workplace learning and knowledge transfer, while the staff saw developmental needs in workplace learning only. However, the managers did not see any developmental needs in workplace learning, which is perhaps not surprising because they believed it to be functioning well already. Instead they saw developmental needs in knowledge transfer. 
Politicians and assistant nurses did not mention communicational processes at all. The differences in perception between organizational levels have been addressed earlier (Gustafsson and Szebehely, 2005; Davies et al. 2006), and it may not be surprising that it was the change agents that expressed the importance of finding new methods of knowledge transfer and improved workplace development. The change agents comprise the group that moves in the midst of the organization and is capable of taking perspectives from the position of care work as well as from the leadership and administrative levels. But in order to develop the knowledge-based organization, it is of vital importance that all the different organizational levels achieve a shared meaning of the present state and the future needs of the organization (Wang and Noe, 2010).

\section{Discussion}

This study shows that the development of a knowledge-based organization is more complex than simply advancing knowledge transfer and establishing shared meanings in and between organizations. Earlier research has shown that it is also dependent on the prerequisites in an organization (Westerberg et al., 2011). In addition, the present study shows that the current conceptions about knowledge-based organizations appear to be related to expectations regarding future events. This implies that these conceptions might be important when planning for the future organizational structure (Henriksen \& Rosenqvist, 2003). This relation may be an expression of the need for a coherent narrative about the organization. In order for such a coherent narrative to be constructed, there is a need for continuity from previous experiences to expected directions for the future (cf. Weick, 1995). In relation to elderly care, continuity is achieved when present prerequisites and communicational processes become points of departure for conceptions of what elderly care will be like in the future. Because of this, themes such as limited resources, research needs, and the use of evidence-based methods recur, regardless of the problem being dealt with.

This study also uncovers an exception to the pattern above in the theme of economic resources, which were not considered an area of development despite being seen as a limiting factor in the present. For the change agents and assistant nurses, this may be a consequence of possibility perceived as influencing economic resources in a knowledge-based organization. According to Casey (2009), the knowledge-based organization is an expression of a neoliberal perspective on organizations where efficiency and productivity are priorities and employees are considered as organizational resources rather than co-creators in design and management. This approach is in conflict with previous social and cultural values about democratic participation in, for example, the economic regulation of an organization. This may be the reason 
why the co-workers in the present study talked about efficiency, knowledge transfer, and workplace learning as development areas in line with a knowledge-based organization, but not about the possibility of influencing economic development within the organization.

However, the co-workers are not the only group that does not consider the economic situation as a developmental area: politicians and managers also share this belief. This may be a result of the new prerequisites for managerial control in the neo-liberal economy, where many employers' focus on cutting costs and increasing productivity in response to regulatory changes in the political and economic environment (Carter et al., 2011). In relation to municipal elderly care in Sweden, regulatory changes have coincided with an increase in the number of elderly people in need of social services and care (SALAR, 2006). In accordance with the functional groups in this study, SALAR (Swedish Association of Local Authorities and Regions) (2010) also argues that there will be a gap between needs and economic resources in future municipal elderly care. Based on the gap between needs and economic resources, the politicians' and managers' views on efficiency may be a response to the need to handle economic changes in the environment within the context of a neo-liberal perspective on the organization.

Furthermore, this understanding of the economic situation, as being out of the hands of the organization, is related to consequences of the practices of New Public Management. These practices affect both elderly care, as described by Gustafsson and Szebehely (2005), and other public organizations, as outlined by Noblet, Rodwell, and McWilliams (2006). For example, different categories emphasized different aspects of the communicational processes and some categories did not mention them at all. One way to interpret this is that all of the groups have recognized the label of knowledge-based organization as legitimate, but have not achieved a collective appropriation of it, a situation which is linked to the collective adaptation and development of a shared meaning by adjusting the label to local needs and constraints (Corradi et al., 2010). Elderly care is an example of what Danemark and Kullberg (1999) and Hasenfeld (1992) have described as a human-service organization (i.e., a public organization in the welfare sector). As such, its existence depends on external support, and therefore it tries to conform to prevailing local norms and conceptions about knowledge-based organizations. Such norms and conceptions may form the basis of a position that the organization should become affiliated with in order to obtain legitimacy (Meyer \& Rowan, 1991).

As with the vision of the knowledge-based organization, it is possible to provide stability and meaning in the organization by adopting abstract labels without a collective appropriation. This, however, leads to stability that lies more in the labels used to define the organization than the meaning attached to those labels (cf. Chreim, 2005). Therefore the ambiguity can create a 
loosely coupled system of actions, ideas, and people with different agendas (Corradi et al., 2010; Lindqvist, 2000; Weick, 1976). As the results of the present study indicate, such a loosely unified system within the organization might also hinder its future development, as its members' interpretations will also affect their behaviour during periods of change (Chreim, 2007; Eden \& Ackermann, 1998). In order to achieve a knowledge-based organization with coordinated strategies for future challenges, the diverse professional groups within the organization need to create a shared meaning through collective appropriation of the organization's main goals - what they must do in order to achieve these goals, not only as an overall effort, but also by common and concrete interpretations of the various problems and goals they face. Otherwise the delivery of, for example, elderly care as a knowledge-based organization in which communicative processes create, embrace, and spread knowledge and expertise effectively, may be hindered.

Finally, this study shows that the concept of a knowledge-based organization is not without contradictions. The economic situation is perceived as impossible to influence, whereas other areas that may be developed are perceived differently on different organizational levels. In addition, the study reveals that a narrative approach is valuable not only for understanding how conceptions of legitimate labels are related to past experiences in an organization, but it is also useful for understanding how conceptions of labels in relation to the future are based on perceptions of the current situation in the organization. Therefore, one contribution of the present study, in relation to use of the narrative method to understand community and change in organizations, is the indication that it is relevant to look also to the future, and not simply to the past.

\section{References}

Arnetz, J. E., \& Hasson, H. (2007). Evaluation of an educational 'toolbox' for improving nursing staff competence and psychosocial work environment in elderly care: Results of a prospective, non-randomized controlled intervention. International Journal of Nursing Studies, 44, 723-735.

Blom, B., \& Nygren, L. (2010). Analysing written narratives: considerations on the 'code-totality problems'. Nordic Journal of Social Research, 1.

Boreham, N., \& Morgan, C. (2004). A sociocultural analysis of organizational learning. Oxford Review of Education, 30(3), 307-325.

Boström, A.-M., Wallin, L., \& Nordström, G. (2007). Evidence-based practice and determinants of research use in elderly care in Sweden. Journal of Evaluation of Clinical Practice, 13, 665-673. 
Carter, B., Danford, A., Howcroft, D., Richardson, H., Smith, A., \& Taylor, P. (2011). 'All they lack is a chain': lean and the new performance management in the British civil service. New Technology, Work and Employment, 26 (2), 83-97.

Casey, C. (2009). Organizations, workers and learning: new prospects for citizenship at work? Citizenship Studies, 13(2), 171-185.

Chase, R. (1997). The knowledge-based organization: an international survey. The Journal of Knowledge Management, 1(1), 38-49.

Chreim, S. (2005). The continuity-change duality in narrative texts of organizational identity. Journal of Management Studies, 42(3), 567-593.

Chreim, S. (2007). Social and temporal influences on interpretations of organizational identity and acquisition integration: A narrative study. Journal of Applied Behavioral Science, 43(4), 449-480.

Czarniawska, B. (1997). Narrating the Organization: Dramas of Institutional Identity. Chicago: University of Chicago Press.

Corradi, G., Gherardi, S., \& Verzelloni, L. (2010). Through the practice lens: Where is the bandwagon of practice-based studies heading? Management Learning, 41(3), 265-283.

Danermark, B., \& Kullberg, C. (1999). Samverkan: välfärdsstatens nya arbetsform [Collaboration: the welfare state's new work form]. Lund: Studentlitteratur.

Davies, J., Heyman, B., Godin, P., Shaw, M., \& Reynolds, L. (2006). The problems of offenders with mental disorders: A plurality of perspectives within a single mental health care organization. Social Science \& Medicine, 63(4), 1097-1108.

De Fina, A., \& Georgakopoulou, A. (2008). Analysing narratives as practices. Qualitative Research 2008, 8(3), 379-387.

Denvall, V. (2008). Evidence in action: a Thompsonian perspective on evidence-based decision-making in social work. European Journal of Social Work, 11(1), 29-42.

Eden, C., \& Ackermann, F. (1998). Making Strategy: The Journey of Strategic Management. London: Sage.

Ellström, E., \& Ekholm, B. (2001). Lärande i omsorgsarbete - en studie av hemtjänsten som lärandemiljö [Learning in care work - a study of home help service as a learning environment]. CMTO, Research Monographs, No. 1, Linköpings universitet.

Engeström, Y. (2001). 'Expansive learning at work: toward an activity theoretical reconceptualisation'. Journal of Education and Work, 14(1), 133-156.

Fraser, H. (2004). Doing narrative research: Analysing personal stories line by line. Qualitative Social Work, 3(2), 179-201.

Gustafsson, R. Å., \& Szebehely, M. (2005). Arbetsvillkor och styrning i äldreomsorgens hierarki - en enkätstudie bland personal och politiker. [Working conditions and 
steering in the hierarchy of elder care: a survey study among Employees and Politicians]. Department of Social Work, Stockholm University.

Hasenfeld, Y. (1992). The nature of human service organizations. In Hasenfeld, Y. (Ed.), Human Services as Complex Organizations (pp. 3-23). Newbury Park: Sage.

Henriksen, E., \& Rosenkvist, U. (2003). Contradictions in elderly care: a descriptive study of politicians' and managers' understanding of elderly care. Health and Social Care in the Community, 11(1), 27-35.

Lieblich, A., Tuval-Mashiach, R., \& Zilber, T. (1998). Narrative Research: Reading, Analysis and Interpretation. Thousand Oaks, Californa: Sage.

Lindqvist, R. (2000). Att sätta gränser [Setting boundaries] Umeå: Boréa.

Ma, Z., \& Yu, K.-H. (2010). Research paradigms of contemporary knowledge management studies: 1998-2007. Journal of Knowledge Management, 14(2), 175-189.

Meyer, J., \& Rowan, B. (1991). Institutionalized organizations: formal structure as myth and ceremony. In Powell, W., \& DiMaggio, P. (Ed.). The New Institutionalism in Organizational Analysis. Chicago: The University of Chicago Press, 41-62.

Miles, M. B., \& Huberman, A. M. (1994). Qualitative Data Analysis: An Expanded Sourcebook. Thousand Oaks, California: Sage.

Ministry of Health and Social Affairs (2007). Regeringsbeslut: Stimulansbidrag till kommuner och landsting för insatser inom vård och omsorg om äldre personer, S2006/9173/ST, S2007/515/ST [Governmental resolution: stimulation grants to municipalities and counties for the investment in the nursing and care of elderly persons]. Socialdepartementet: 2007.

Nixon, S., \& Murr, A. (2006). Practice learning and the development of professional practice. Social Work Education, 25(8), 798-811.

Noblet, A., Rodwell J., \& McWilliams, J. (2006). Organizational change in the public sector: Augmenting the demand control model to predict employee outcomes under New Public Management. Work \& Stress, 20(4), 335-352.

Pentland, B. T. (1999). Building process theory with narrative: from description to explanation. Academy of Management Review, 24(4), 711-724.

Salander, P. (2002). Bad news from the patient's perspective: An analysis of the written narratives of newly diagnosed cancer patients. Social Science \& Medicine, 55(5), 721-732.

SALAR (Swedish Association of Local Authorities and Regions) (2006). Care of the Elderly in Sweden Today. Report, Swedish Association of Local Authorities and Regions, Stockholm. 
SALAR (Swedish Association of Local Authorities and Regions) (2010). Challenges for the Future. Report, Swedish Association of Local Authorities and Regions, Stockholm.

Sias, P.M., Heath, R.G., Perry, T., Silva, D., \& Fix, B. (2004). Narratives of workplace friendship deterioration. Journal of Social and Personal Relationships, 21(3), 321-340.

SOU 2007:88 Att lära nära - stöd till kommuner för verksamhetsnära kompetensutveckling inom omsorg och vård av äldre. [Learning closely: support for municipalities for the development of hands-on competence in care and nursing of the elderly] Swedish Government Official Reports 2007:88.

Svanström, M. (2008). Projektplan för Stimulansmedel i Umeå kommun. Socialtjänsten i Umeå kommun [Project Plan for Stimulation Grants in Umeå municipality: social services in Uneå municipality.] Umeå Municipality] [in Swedish].

Törnquist, A. (2004). Vad man ska kunna och hur man ska vara - en studie om enhetschefers och vårdbiträdens kompetens inom äldreomsorgens särskilda boendeformer. [What one should know and how one should be: a study on unit managers' and nursing assistants' competence in elderly care, especially in nursing homes] Doctoral dissertation. The Stockholm Institute of Education, Department of Society, Culture and Learning. Stockholm: HLT Förlag.

VP (2009). Lokal verksamhetsplan för 2009. [Local activity plan for 2009] Umeå kommun: Socialnämnd/Socialförvaltning. [Local business plan for 2009. Umeå Municipality] [in Swedish].

Wang, S., \& Noe, R. (2010). Knowledge sharing: a review and directions for future research. Human Management Review, 20(2), 115-131.

Weick, K. (1976). Educational organizations as loosely coupled systems. Administrative Science Quarterly, 21(1), 1-19.

Weick, K. (1995). Sensemaking in Organizations. Thousand Oaks, California: Sage.

Westerberg, K., Hjelte, J., Brännström, J., \& Hyvönen, U. (2011). The meaning of a knowledge-based organization in Swedish municipal elderly care. Social Work Education, 31(4), 465-484. 